\title{
Competencies for a United States Horticulture Undergraduate Major: A National Delphi Study
}

\author{
Ashley R. Basinger ${ }^{1}$, Cynthia B. McKenney ${ }^{2,4}$, and Dick Auld ${ }^{3}$
}

\begin{abstract}
ADDITIONAL INDEX WORDs. curriculum, degree program
Summary. A competency-based curriculum involves defining set knowledge, skills, and values for a particular education. Many technical undergraduate majors have developed a list of competencies for evaluation, assessment, and improvement of higher education curriculum. This national Delphi study is the first concise list of competencies described for a horticulture curriculum. A sample of horticulture educators within the United States $(n=22)$ were selected as experts in horticulture education and curriculum improvement through an e-mail requirement letter sent to university chairs. Information on age, teaching position, and bachelor's degree earned by panel member and department size was collected and it was determined these factors did not impact the panel members' decision on ranking competencies. The three-round Delphi study results provide a list of competencies considered to be important or not important in the general horticulture education field. The final compilation of competencies describes a total of 108 specific learning outcomes, with 41 horticulture technical competencies, 34 life science technical competencies, and 33 professional competencies. Overall, this competency skills list may be useful for future assessment and development of horticulture curricula.
\end{abstract}

$\mathrm{E}$ vidence of a quality education is the primary agenda of accreditation agencies in their evaluation of American higher education institutions. The American academe is increasingly viewed as an economic service providing industry a competitive edge. Employers and financial backers of these institutions desire more than traditional evidence such as grades, certificates, and degrees to measure student's knowledge, skills, and abilities (Baker, 2004). In "Knowing What Students Know" (Pellegrino et al., 2001), one recommendation for institutions to improve quality is to use large-scale assessment to sample a broad range of competencies shared by teachers, students, and other education stakeholders. Pellegrino et al. (2001) goes on to say, "Knowledge and skills to be assessed and the criteria for judging the desired outcomes should be clearly specified and available to all potential examinees." Knowledge and skill can be measured by defined competencies, which are established behavior

\footnotetext{
Department of Plant and Soil Science, Texas Tech University, Lubbock, TX 79409

${ }^{1}$ Former Graduate Student.

${ }^{2}$ Associate Professor.

${ }^{3}$ Professor.

${ }^{4}$ Corresponding author. E-mail: cynthia.mckenney@ ttu.edu.
}

requirements needed for students to be successful.

Competencies have been used in curriculum evaluation and reform to measure learning and to keep academic entities accountable for the growth of that learning. Many undergraduate majors have defined competencies assessing effectiveness of their degree programs. In the United States, the horticulture undergraduate major has no defined set of national competencies and currently does not have a nationwide accreditation organization that reviews these programs. In the 1980s, the American Society for Horticulture Science created a curriculum committee to review curricula for the major and to determine their relevancy (Hegwood and Merritt, 1987). From this committee, a summary of core requirements was established for a certified horticulturist designation. The requirements included required courses in the degree program as well as a minimum of five years of experience in the field. While addressing core requirements, these efforts and those of the committee that has updated this document fall short of setting specific course content and required skills needed within the horticulture field (American Society for Horticultural Science, 2008). Completion of a competency-based curriculum for the horticulture major would facilitate unity in horticulture programs and provide assurance to industry professionals of the education potential employees have acquired. The purpose of this study was to develop a competency-based list for the horticulture undergraduate major using a national Delphi study to gather input from horticultural experts in academia. The Delphi method is based on a structured process for collecting and distilling knowledge from a group of experts by means of a series of questionnaires interspersed with controlled opinion feedback (Alder and Ziglio, 1996). This method of surveying individuals and collecting interactive comments provides a useful venue when creating a collaborative work.

\section{Materials and methods}

The research design consisted of a three-round Delphi method technique consisting of a sequential series of questionnaires sent to a panel of horticulture undergraduate educators involved in general horticulture. The population for this study was comprised of general horticulture leaders from specific horticulture professional organizations within the United States. Childers (1989) determined the total number of horticulture programs is approximately 100 . A recruitment letter was emailed to the 68 identifiable department heads of horticulture programs within the United States. Individual department heads were requested to forward the e-mail to the horticultural curriculum expert within their department. These individuals became panel members when they sent an e-mail to the researcher accepting participation in the study. A second letter was then emailed to the newly identified panel members with a hyperlink to round 1 of the survey. Nonrespondents were contacted during round 1 by e-mail and then by phone. This recruitment increased the sample from 19 to 22 panel members. The sample size for the expert panel of horticulture educators was $\mathrm{n}=22(32 \%)$ for round $\mathrm{l}, \mathrm{n}=19$ $(27.9 \%)$ for round 2 , and $\mathrm{n}=17$ (25\%) for round 3 .

The instrument was a modified questionnaire using a list of competencies from Iowa State University's Horticulture Assessment Survey and "Making the Match Questionnaire on Skills" (Evers, 1998). Permission was gained to use a modification of 
the Iowa State Assessment Survey (A.M. VanDerZanden, personal communication). The response choices used a five-point Likert-type scale consisted of the following choices: 5 = very important, $4=$ important, $3=$ neutral, $2=$ unimportant, and $1=$ very unimportant. After the end of each section, a comment box was provided for any new competencies the panelist wished to add or suggestions for changing an existing competency (Bailey-Evans, 1994; Keech, 1998). The second section contained 13 demographic questions asking about the respondent's personal/professional characteristics, the university's characteristics, and the current assessment measures already in place. The demographic questions allowed the participant to respond by checking the appropriate boxes, as well as provided for open-ended responses.

The instrument was tested for face validity and reliability through a pilot survey. The pilot survey was administered to a selection of faculty from other universities to evaluate content, face validity, and clarity of the first round questionnaire. The sample of participants for the pilot test questionnaire $(\mathrm{n}=6)$ contained horticulture educators from Texas Tech University, Texas A\&M
University, University of Arkansas, Iowa State University, and Utah State University. The criterion for the participants was experience in horticulture education, higher education, or educational surveys. After the pilot survey, a total of 25 subdisciplines of horticulture and 97 competencies were added to round 1 .

In round 1 , panel members were asked to evaluate each competency listed concerning its importance to the horticulture undergraduate program. Each competency had to have $75 \%$ of the participants agree that it should be retained to remain on the list of competencies for the horticulture undergraduate major in the next round. Any competencies not receiving a ranking of $75 \%$ acceptance rate were removed from the questionnaire. Protocol for selecting the cutoff point for Delphi studies usually varies between a $65 \%$ and $75 \%$ acceptance rate. Round 2 consisted of new competencies added by the panel members, high-ranking scores from round 1 , and a new section with ranking the main topics of the competencies. The round 3 questionnaire was the final round of ranking the competencies and did not include the option of adding any new competencies. Table 2 represents the final revision of the questionnaire that was used to rank the competencies.

The Delphi study data were ordinal in nature; thus, nonparametric techniques were used (Siegel, 1956). The Kruskal-Wallis test was used to analyze differences in independent variables among groups. The significance level for determining statistical difference between groupings mean ranks was held at $P \leq 0.05$ throughout the study.

\section{Results and discussion}

Panel member locations and academic affiliations collected during round 1 are presented in Table 1 . Eighteen states were represented in this national Delphi study. Characteristics of the panel members are described to show qualifications and homogeneity within the sample population. A small sample of 10 to 15 respondents is adequate for a sample when the group is homogeneous (Ferguson, 2000). In analyzing the highest education degree achieved, 19 of the panel members (86.3\%) received their doctorate, with six continuing on with a postdoctorate. Three members' highest education level was a Masters degree (13.6\%). Horticulture was the most frequent major for all three degree levels, with

Table 1. Locations and work areas for 22 participating Delphi study panel members identifying competencies with a U.S. horticulture baccalaureate degree.

\begin{tabular}{|c|c|c|}
\hline${\text { Academic } \text { area }^{z}}$ & University affiliation & Location \\
\hline Plant Sciences & University of Arizona & Tucson, AZ \\
\hline Horticulture and Crop Science & California State Polytechnic University & San Luis Obispo, CA \\
\hline Plant and Soil Science & University of Delaware & Newark, DE \\
\hline Horticultural Science & Florida Southern College & Lakeland, FL \\
\hline Horticulture & University of Georgia & Athens, GA \\
\hline Horticulture & Iowa State University & Ames, IA \\
\hline Agriculture & Murray State University & Murray, KY \\
\hline Plant and Soil Sciences & Mississippi State University & Mississippi State, MS \\
\hline Agriculture, Biology, Chemistry, and Physics & Lincoln University & Jefferson City, MO \\
\hline Plant Sciences and Plant Pathology & Montana State University & Bozeman, MT \\
\hline Agronomy and Horticulture & University of Nebraska & Lincoln, NE \\
\hline Horticulture, Forestry, and Landscape Parks & South Dakota State University & Brookings, SD \\
\hline Agriculture & Sam Houston State University & Huntsville, TX \\
\hline Agriculture & Texas State University & San Marcos, TX \\
\hline Plant and Soil Science & Texas Tech University & Lubbock, TX \\
\hline Plants, Soils, and Climate & Utah State University & Logan, UT \\
\hline
\end{tabular}

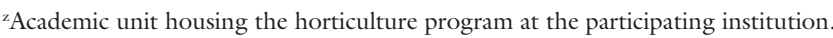


Table 2. Delphi study topic area, round of acceptance, competency description, and percentage of acceptance after three rounds of panel members' surveys to determine the inclusion of specific competencies in an undergraduate horticulture curriculum.

\begin{tabular}{|c|c|c|c|}
\hline $\begin{array}{l}\text { Topic area that } \\
\text { includes the } \\
\text { competency }\end{array}$ & $\begin{array}{l}\text { Delphi round } \\
\text { no. when } \\
\text { accepted }\end{array}$ & Competency description & $\begin{array}{l}\text { Acceptance } \\
\text { rate }(\%)^{Z}\end{array}$ \\
\hline \multirow[t]{7}{*}{ Plant identification } & & & 100 \\
\hline & 1 & $\begin{array}{l}\text { Identify plants commonly used in the discipline by scientific } \\
\text { and common name }\end{array}$ & 100 \\
\hline & 1 & Use fundamental knowledge of taxonomy & 86 \\
\hline & 2 & $\begin{array}{l}\text { Identify geographic origin, ecology, and adaptability } \\
\text { of common plants to environmental conditions }\end{array}$ & 80 \\
\hline & 2 & Describe basic family characteristics & 70 \\
\hline & 2 & Find and examine sources of information to identify plants & 90 \\
\hline & 2 & $\begin{array}{l}\text { Recognize visually common cultivars used in field } \\
\text { of interest }\end{array}$ & 70 \\
\hline \multirow{23}{*}{$\begin{array}{l}\text { Field and greenhouse } \\
\text { management }\end{array}$} & & & 95 \\
\hline & 1 & Define and select planting methods for different horticulture crops & 100 \\
\hline & 1 & $\begin{array}{l}\text { Construct and manage different irrigation, fertilization, } \\
\text { and pest management systems }\end{array}$ & 95 \\
\hline & 1 & $\begin{array}{l}\text { Understand formulations and manage soil-based, } \\
\text { artificial substrates used in horticulture }\end{array}$ & 91 \\
\hline & 1 & $\begin{array}{l}\text { Identify strategies for efficient and abundant production, harvest, } \\
\text { and storage of high-quality crops (food, flowers, and turf) }\end{array}$ & 91 \\
\hline & 1 & Perform techniques in sexual and asexual propagation of plants & 91 \\
\hline & 2 & Understand construction and maintenance of a greenhouse & 95 \\
\hline & 2 & $\begin{array}{l}\text { Know how to apply appropriate plant management involving } \\
\text { pruning, training, plant growth regulators, and environment } \\
\text { (light, nutrition, water, and soil) }\end{array}$ & 95 \\
\hline & 1 & Design an appropriate irrigation schedule for a landscape & 77 \\
\hline & 1 & Design an appropriate fertility schedule for a landscape & 82 \\
\hline & 1 & Design an appropriate mowing schedule for a landscape & 73 \\
\hline & 2 & Determine appropriate time management for task & 70 \\
\hline & 2 & Understands landscape bidding & 80 \\
\hline & 2 & Recognize appropriate placing for specific plants & 90 \\
\hline & 3 & $\begin{array}{l}\text { Understand how and why of planting a plant ( size, depth of hole, backfill, } \\
\text { and where the root collar or crown must be relative to grade) }\end{array}$ & 100 \\
\hline & 3 & Recognize and solve root problems such as encircling roots & 88 \\
\hline & 1 & Understand effects of pest control on environment & 100 \\
\hline & 1 & Design and calculate appropriate application of agricultural compounds & 96 \\
\hline & 1 & $\begin{array}{l}\text { Identify and apply appropriate safety procedure } \\
\text { regarding agricultural compounds }\end{array}$ & 95 \\
\hline & 2 & $\begin{array}{l}\text { Recognize governmental regulations that impact agricultural chemical } \\
\text { application and use }\end{array}$ & 90 \\
\hline & 2 & $\begin{array}{l}\text { Design an appropriate chemical application schedule } \\
\text { (time, rotation, and limitations) }\end{array}$ & 90 \\
\hline & 2 & Calculate and make conversions for applying & 90 \\
\hline & 2 & Be able to obtain a pesticide license & 85 \\
\hline \multirow{2}{*}{ Technology } & & & 95 \\
\hline & 3 & Understand the content of a pesticide label & 100 \\
\hline
\end{tabular}


Table 2. (Continued) Delphi study topic area, round of acceptance, competency description, and percentage of acceptance after three rounds of panel members' surveys to determine the inclusion of specific competencies in an undergraduate horticulture curriculum.

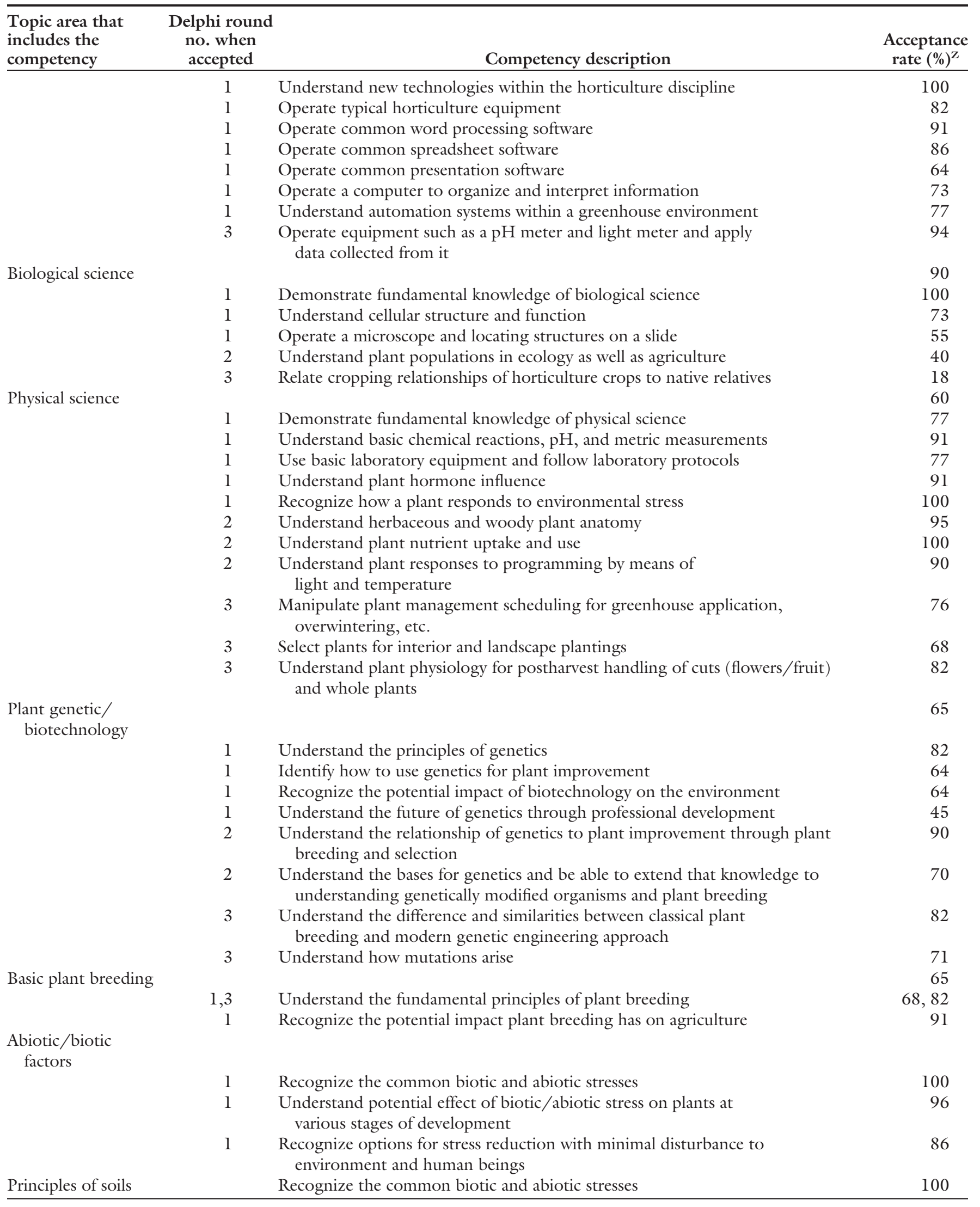


Table 2. (Continued) Delphi study topic area, round of acceptance, competency description, and percentage of acceptance after three rounds of panel members' surveys to determine the inclusion of specific competencies in an undergraduate horticulture curriculum.

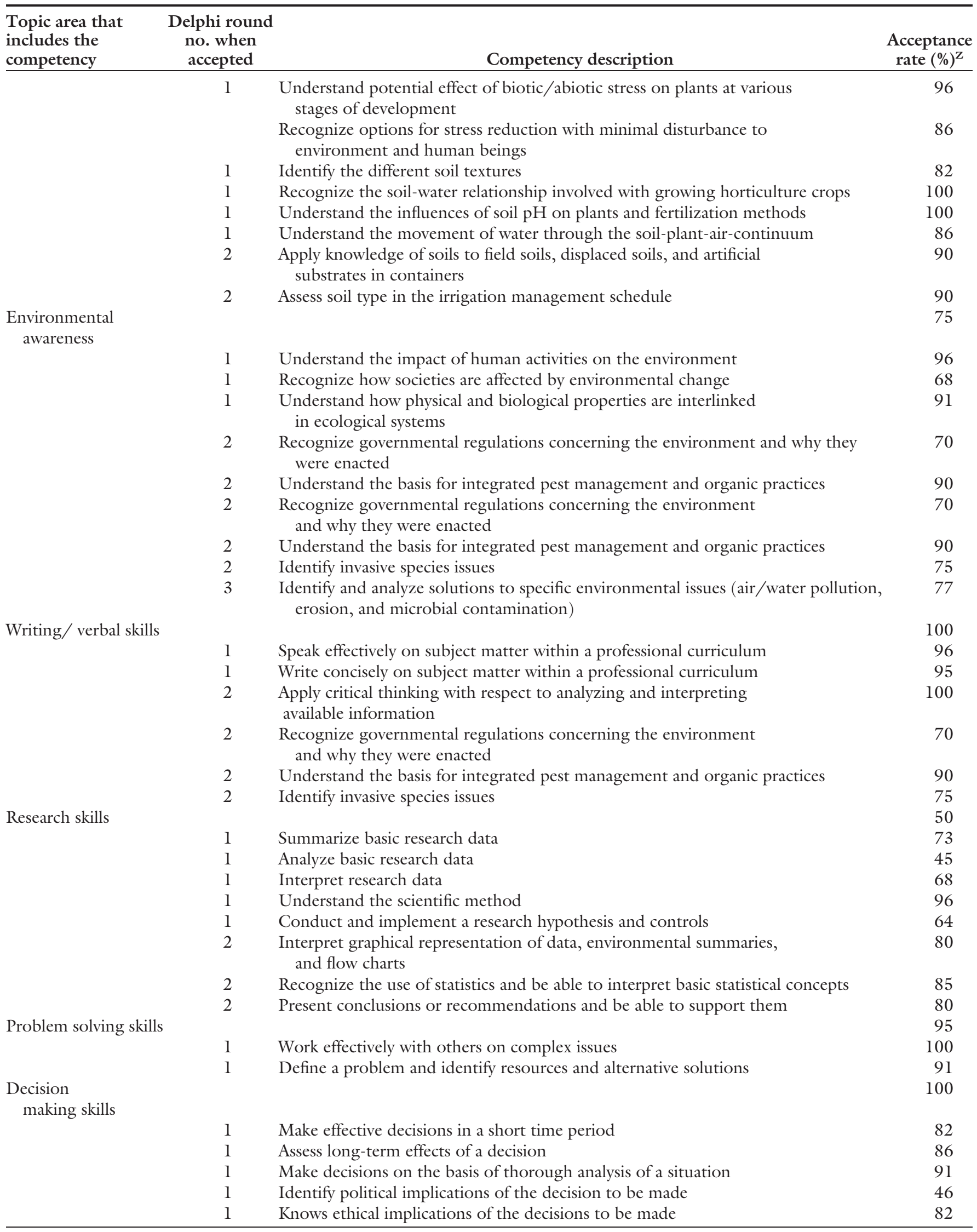


Table 2. (Continued) Delphi study topic area, round of acceptance, competency description, and percentage of acceptance after three rounds of panel members' surveys to determine the inclusion of specific competencies in an undergraduate horticulture curriculum.

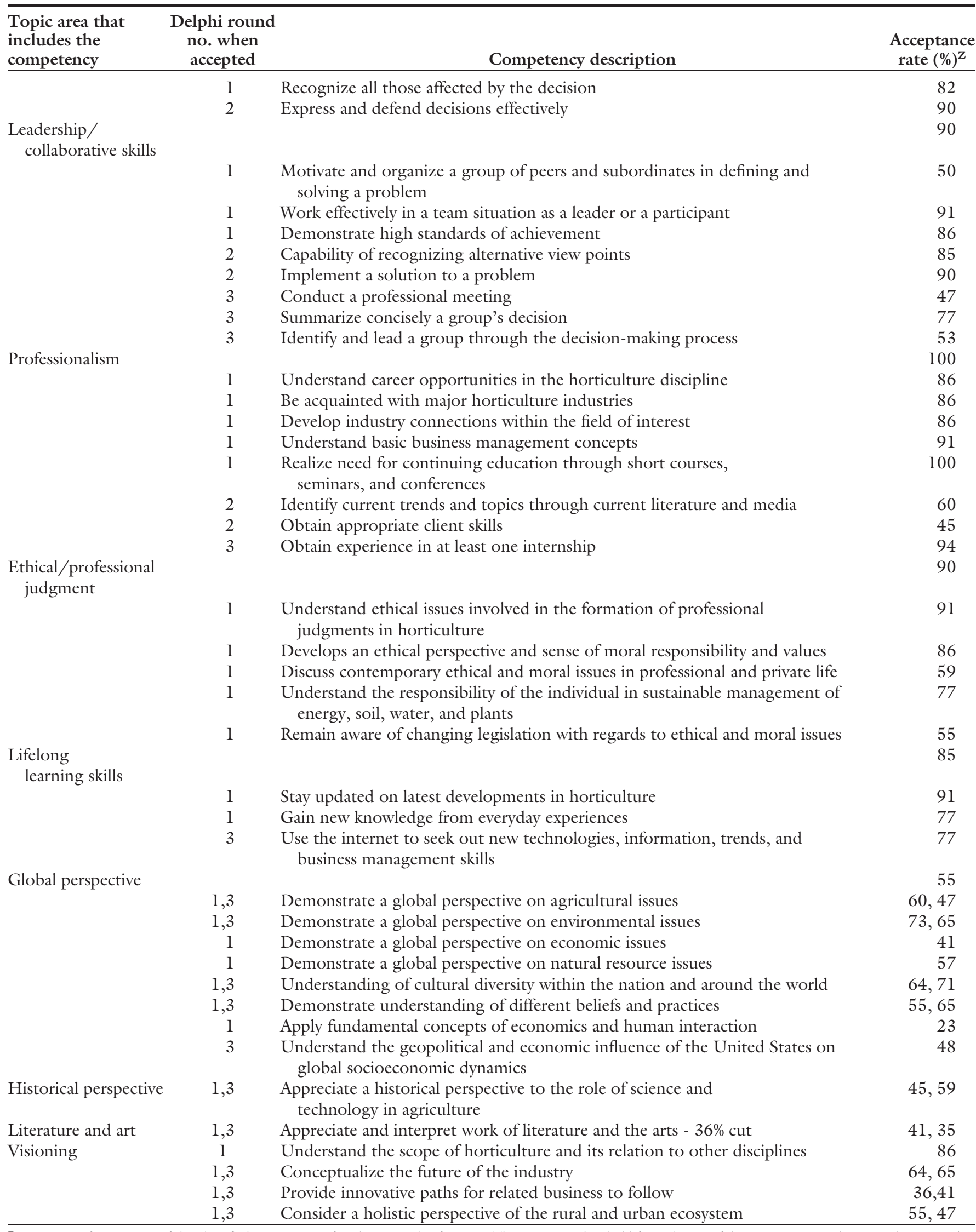

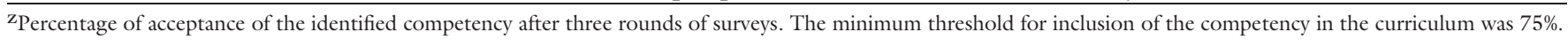


over $77 \%$ of the participants earning their B.S. and M.S. in horticulture, and more than $50 \%$ achieving their Ph.D. in horticulture. All doctoral degrees were obtained in a plant science-related field, with 12 of the 19 obtaining their doctorate specifically in horticulture.

The central tendency of the panel member showed that they typically: 1) had a Ph.D. in horticulture, 2 ) held a position of assistant professor or full professor, 3 ) were 51 to 60 years in age, and 4 ) had been teaching for 21 or more years. The average expert's institutional size was 15,000 to 25,000 students. The department size was between 50 and 200 students with the associated unit participating in six or more years of assessment. From these profile demographics, it was determined the targeted audience had been sampled. Kruskal-Wallis analysis did not detect a difference in the rankings of a panel member with respect to their baccalaureate degree, age, position, or department size.

In round 1,25 horticulture subdiscipline areas were introduced in the study and 17 of these were approved in round 3 . In addition, a total of 108 competencies were approved in the final round. Topics and competencies were placed into the following three categories: 1) horticulture technical competencies, 2 ) life science competencies, and 3 ) professional competencies. Horticulture technical competencies had 41 elements approved, which was the highest number of all the categories. Life science and professional competencies also maintained a high level of acceptance, with 34 and 33 competencies approved, respectively.

The following horticulture subdisciplines received 95\% tol00\% importance rating for including in the horticulture curriculum: 1) plant identification, 2) field and greenhouse management, 3) landscape management, 4) agricultural chemicals, and $5)$ technology. The horticulture experts did not discuss the survey with anyone and still retained a uniform understanding of what the horticulture major should contain. Even though there has not been a formal national competency curriculum, this uniformity reveals an equality of standards for the horticulture curriculum.

The following subdisciplines were approved for the life science competencies: 1) biological science, 2) plant physiology, 3) abiotic/biotic factors, 4) principles of soils, and 5) environmental awareness. Physical science, plant genetics/biotechnology, and plant breeding ranked lower than $75 \%$; thus, they were eliminated from the horticulture curriculum. The low importance ranking of these subdisciplines may have been due to the trend to reduce the total required hours for a horticulture undergraduate degree. In addition, plant genetics/biotechnology, physical science, and plant breeding may have also been cut due to these courses being housed in separate departments at many institutions.

The professional disciplines approved are the following: 1) writing/verbal, 2) problem solving, 3) decision making, 4) leadership/collaborative, 5) professionalism, 6) ethical/professional judgment, and 7) lifelong learning. Professional disciplines eliminated were global perspective, historical perspective, literature and art, and visioning. These disciplines frequently fall under the general education curriculum of many institutions, thus they may not have been viewed as part of the horticulture major. Similarly, global perspectives may have been considered a multicultural class. Even though the visioning discipline was eliminated from the curriculum, the competency of "understand the scope of horticulture and its relation to other disciplines" had a high approval of $86 \%$.

The main objective for this study was to describe a set of competencies necessary for the horticulture undergraduate major. This extensive horticulture competency curriculum list is available to aid horticulture departments in developing a competency curriculum that meets their individual needs. Assessment has not become an accepted part of scholarly activity; however, as long as the higher education accrediting organizations require documentation of how these practices are implemented, horticulture departments across the nation will continue to be interested in this area of study.

\section{Literature cited}

Alder, M. and E. Ziglio. 1996. Gazing into the oracle: The Delphi method and its application to social policy and public heath. Jessica Kingley, London, PA.

American Society for Horticultural Science. 2008. ASHS Certified Horticulturist: A program of the American Society for Horticultural Science. 30 Dec. 2008. <http://www.ashs.org/downloads / CHbrochure.pdf $>$.

Bailey-Evans, F. 1994. Enhancing the agricultural communications curriculum: A national Delphi-study. Texas Tech University, Lubbock, TX. MS Thesis.

Baker, R. 2004. Keystones of regional accreditation: Intentions, outcomes, and sustainability, p. 1-14. In: P. Hernon and R. Duncan (eds.). Outcomes assessment in higher education: Views and perspectives. Libraries Unlimited, London.

Childers, N.F. 1989. Educational institutions offering horticulture and or landscape architecture in the United States and Canada. HortScience 24:211-217.

Evers, F.T. 1998. The bases of competence: Skills for lifelong learning and employability. Jossey-Bass, San Francisco.

Ferguson, S.D. 2000. Researching the public opinion environment: Theories and methods. Sage Publications, Thousand Oaks, CA.

Hegwood, D.A. and R.H. Merritt. 1987. Horticultural curricula can benefit from national initiatives. HortScience 22:351352.

Keech, K.M. 1998. Industry-based curriculum competencies for entry-level retail management positions: A national Delphistudy. Texas Tech University, Lubbock, TX, Ph.D. Dissertation.

Pellegrino, J.W., N. Chudowsky, and R. Glaser (eds.). 2001. Knowing what students know: The science and design of educational assessment. National Academy Press, Washington, DC. 